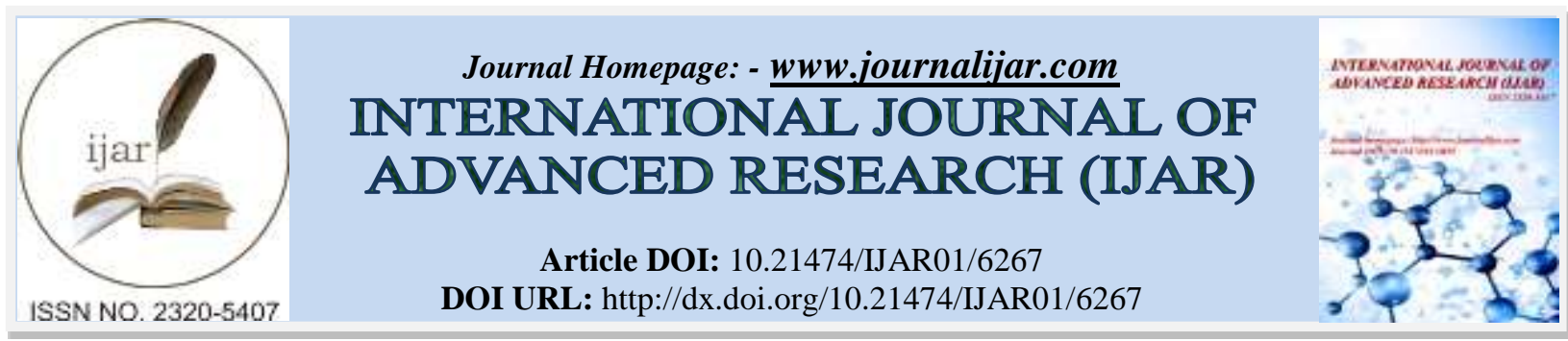

RESEARCH ARTICLE

\title{
A STUDY ON IMPACT OF CELEBRITY ENDORSED ADS ON CONSUMERS: A STUDY IN SHIMOGA CITY.
}

Mrs. Deepa $\mathbf{L}^{1}$ and Dr. Giridhar K. $\mathbf{V}^{\mathbf{2}}$.

1. Research Scholar, Sahyadri Com. \& Management College, Kuvempu University, Shimoga-577203.

2. Assistant Professor, Sahyadri Com.\& Management College, Kuvempu University, Shimoga-577203.

\section{Manuscript Info}

Manuscript History

Received: 10 November 2017

Final Accepted: 12 December 2017

Published: January 2018

Key words:-

Celebrity endorsement, Celebrity endorser, advertisement, Customer brand acceptability.

\section{Abstract}

From past 20 years or so the trend of using a celebrity to endorse a brand has become popular. The power of endorsement of celebrities is accepted by everyone and most of the marketing people say that these celebrities have a great impact on altering the purchase decision especially of the young consumers. This is because of these reasons that most of the firms spend crores of rupees in endorsing popular celebrities. Since the very beginning of celebrity culture, celebrities have been used as role models especially by female consumers in the area of personal appearance. In our modern society advertising companies take full advantage of this fact, by the use of celebrity endorsement. Advertising is the most common and effective tool used in creating awareness and convincing customers about their brand. The objective of this study is to gain a deeper understanding of the impact of celebrity endorsers leading to purchasing decisions and behavioral intentions of male and female consumers. The findings revealed that consumers perceive the celebrity endorser as a role model who influences their buying decisions. The research also found that negative celebrity information will negatively influence consumers purchasing decisions due to the reason that the society tends to relate a celebrity's personal life to his profession.

Copy Right, IJAR, 2018,. All rights reserved.

\section{Introduction:-}

Advertisement has become an integral part in today's marketing scenario. Advertising upholds the ideas, commodities and services of a recognized advertiser, which provides as a communication link between the producer and potential buyers. In today's glamorous world where people remember things which are either glamorized or they provide them a reason to remember them. Celebrity endorsement helps most of the organizations to work on these affairs. Celebrities apart from their primary job of playing, acting, modeling etc., are also helpful in promoting brand. Since the very beginning of celebrity culture, celebrities have been used as role models this generation.

In our modern society advertising companies take full advantage of this fact, by the use of celebrity endorsement. Advertising is the most common and effective tool used in creating awareness and convincing customers about their brand. From past 20 years or so the trend of using a celebrity to endorse a brand has become popular. The power of endorsement of celebrities is accepted by everyone and most of the marketing people say that these celebrities have a great impact on altering the purchase decision especially of the young consumers. This is because of these reasons 
that most of the firms spend crores of rupees in endorsing celebrities. There are two main ways that celebrities can positively affect a brand's image. The first is by creating "borrowed equity" in which the celebrity heightens awareness of the brand and pulls more potential consumer's attention to their products. The second is the spokesperson which usually increases the brand's equity- the positive qualities of the celebrity spokesperson are projected onto the brand and therefore reinforces the brand values.

\section{Objectives of the Study:-}

- To measure the impact of celebrities through advertisements on gender.

- To find how the advertisements are perceived by consumers and is there any difference between men and women in the way they see the advertisements.

- $\quad$ To examine the impact of celebrity endorsement on consumer buying behaviour of Shimoga city.

\section{Research Hypothesis:-}

$\mathrm{H}_{1}$ : Gender doesn't show any significant difference in their favorability towards celebrity endorsement.

$\mathrm{H}_{2}$ : There exists no significant difference among the gender in their opinion towards the negative impact of the celebrity endorsement.

$\mathrm{H}_{3}$ : There exists no significant difference among the gender in their attitude against advertisement

\section{Research Methodology and Design:-}

The research is quantitative and descriptive in nature. Both primary and secondary data sources have been collected. The primary data is collected through structured questionnaire from the 125 respondents of Shimoga city but the proper responses were received from 110 respondents. The secondary data is collected from books, journals, periodicals, and internet.

a. Area of the study: The Study is conducted in Shimoga city.

b. Sampling method: The sample method used to select the area for this study is random sampling technique. The sample method that was used to collect primary data from the population was convenience sampling.

c. Plan of analysis: Statistical tools are used for analyzing the primary data. The Chi - Square Test was used to test the hypothesis; Mean scores and Z-Test was used to find out the impact of celebrities through advertisements on consumers, for the same SPSS version 19.0 has been employed.

\section{Data analysis and Interpretation of the Result:-}

The data analysis and interpretation has been discussed in the following tables and paragraphs as under.

a. Demographical Analysis:

\begin{tabular}{|c|c|c|c|c|c|}
\hline \multicolumn{2}{|l|}{ Valid } & Frequency & Percent & Valid Percent & $\begin{array}{l}\text { Cumulative } \\
\text { Percent }\end{array}$ \\
\hline \multirow[t]{5}{*}{ Age } & 20-30 Years & 52 & 47.27 & 47.27 & 47.27 \\
\hline & $30-40$ Years & 32 & 29.10 & 29.10 & 76.37 \\
\hline & $40-50$ & 15 & 13.63 & 13.63 & 90.00 \\
\hline & 50 and Above & 11 & 10.00 & 10.00 & 100 \\
\hline & Total & 110 & 100 & 100 & \\
\hline \multirow[t]{3}{*}{ Gender } & Male & 55 & 50 & 50 & 50 \\
\hline & Female & 55 & 50 & 50 & 100 \\
\hline & Total & 138 & 100 & 100 & \\
\hline
\end{tabular}

Source: Field Survey

From the above table, it can be depicted that the distribution of respondents based on Age wise, out of 110 respondents, maximum respondents (52) fall between the age 20 to 30 years, followed by 32 respondents fall between the age 30 to 40 years, followed by 15 respondents fall between 40 to 50 years and the remaining respondents (11) are above 50 years. The distribution of respondents based on Gender wise are, 55 respondents are Males. 
b. Medium for Advertisement Analysis

Table No. - 2: Distribution of respondents based on the frequency of watching celebrity endorsed advertisements and preference of celebrity in advertisements. How frequently do you come across celebrity endorsed ads?

\begin{tabular}{|l|l|l|l|l|l|}
\hline \multicolumn{2}{|c|}{} & Frequency & Percent & Valid Percent & Cumulative Percent \\
\hline \multirow{7}{*}{ Valid } & Repeatedly & 102 & 92.72 & 92.72 & 92.72 \\
\cline { 2 - 6 } & Rarely & 08 & 7.28 & 7.28 & 100 \\
\cline { 2 - 6 } & Total & 110 & 100 & 100 & \\
\hline \multicolumn{6}{|c|}{ Do you prefer to see celebrities in advertisements? } \\
\hline \multirow{6}{*}{ Valid } & Yes & Frequency & Percent & Valid Percent & Cumulative Percent \\
\cline { 2 - 6 } & No & 95 & 86.36 & 86.36 & 86.36 \\
\cline { 2 - 6 } & Not Particular & 05 & 4.54 & 4.54 & 90.90 \\
\cline { 2 - 6 } & Total & 10 & 9.10 & 9.10 & 100 \\
\hline
\end{tabular}

Source: Field Survey

The above table gives a clear picture of respondents' frequency of coming across the celebrity endorsed advertisements. It expresses that, $92.72 \%$ (102) of surveyed population repeatedly watch and remaining $7.28 \%(08)$ of them rarely watch the advertisements endorsed by celebrity. It also depicts that dose the consumer prefer to see celebrities in advertisement, out of the surveyed population $86.36 \%$ (95) of the respondents say 'Yes', and just $4.54 \%(05)$ respondents say 'No' and remaining $9.10 \%(10)$ respondents say that they are not particular. It is very clear from the above table that, why the products endorsed by celebrity are gaining more importance in the eyes of consumers.

\section{c. Statement analysis}

\begin{tabular}{|c|c|c|c|c|}
\hline \multirow{3}{*}{$\begin{array}{l}\text { Sl. } \\
\text { No. }\end{array}$} & \multirow{3}{*}{ Statement } & Female & Male & \multirow{3}{*}{ Z-Test } \\
\hline & & \multirow{2}{*}{\multicolumn{2}{|c|}{$\begin{array}{l}\text { Min } 1 \text { to } 5 \\
\text { (Mean Value) }\end{array}$}} & \\
\hline & & & & \\
\hline 1. & $\begin{array}{l}\text { I believe that celebrities in advertisement will help me in choosing the right } \\
\text { product and brand }\end{array}$ & 3.49 & 3.34 & 2.92 \\
\hline 2. & $\begin{array}{l}\text { According to me trustworthiness of the celebrity also affect my buying } \\
\text { behavior }\end{array}$ & 3.77 & 3.71 & 0.83 \\
\hline 3. & Expertise of the celebrity also influence my buying behavior & 3.39 & 3.22 & 1.56 \\
\hline 4. & I purchase products depending on image of the celebrity & 3.66 & 3.43 & 1.98 \\
\hline 5. & According to me sex of celebrity also affect my buying behaviors & 3.48 & 3.17 & 2.38 \\
\hline 6. & $\begin{array}{l}\text { I am very much attracted by the beauty of celebrity which influence my } \\
\text { buying behavior }\end{array}$ & 3.82 & 3.40 & 2.23 \\
\hline 7. & $\begin{array}{l}\text { For me, negative information of celebrity will negatively influence my } \\
\text { purchasing decisions }\end{array}$ & 3.77 & 3.71 & 0.83 \\
\hline
\end{tabular}

Source: Field Survey

First statement was "I believe that celebrities in advertisement will help me in choosing the right product and brand.", result reveals that the mean score of female respondents (3.49) is higher than male respondents (3.34) but Z value (2.92) is greater than 1.96 at 5 percent level of significance. This shows that there is significant difference between male and female respondent's opinion. Female respondents are more strongly convinced to choose the right product and brand if endorsed by celebrity. Second statement was "According to me trustworthiness of the celebrity also affects my buying behavior", Result shows that the mean score of male respondents (3.77) higher than female respondents (3.71) but $\mathrm{Z}$ value (0.83) is less than 1.96 at 5 percent level of significance. This shows that there is statistically no difference between female and male respondents opinion. Both have same opinion that trustworthiness of celebrity affects their buying behavior".

Third statement was "expertise of the celebrity also influences my buying behavior", finding indicate that the mean score of female respondents (3.39) higher than male respondents (3.22) but $Z$ value (1.56) is less than1.96 at 5 percent level of significance. This shows that there is statistically no difference between female and male 
respondents opinion. Both have same opinion that expertise of celebrity also influences to their buying behavior". Fourth statement was "I purchase products depending on image of the celebrity", result shows that the mean score of female respondents (3.66) is higher than male respondents (3.43) but $\mathrm{Z}$ value (1.98) is greater than 1.96 at 5 percent level of significance. This shows that there is significant difference between female and male respondent's opinion. Female respondents are more strongly convinced that they purchase their product depending on the image of the celebrity.

Fifth statement was "According to me sex of celebrity also affect my buying behaviors", result indicates that the mean score of female respondents (3.48) is higher than male respondents (3.17) but $\mathrm{Z}$ value (2.38) is greater than 1.96 at 5 percent level of significance. This shows that there is significant difference between female and male respondent's opinion. Female respondents are more strongly agree that sex of celebrity also effect to their buying behaviors. Sixth statement was "I am very much attracted by the beauty of celebrity which influence my buying behavior.", result indicates that the mean score of female respondents (3.82) is higher than male respondents (3.40) but $\mathrm{Z}$ value (2.23) is greater than 1.96 at 5 percent level of significance. This shows that there is significant difference between female and male respondent's opinion. Female respondents are more strongly agree that their buying behavior is influenced by the beauty of celebrity.

Seventh statement was "For me, negative information of celebrity will negatively influence my purchasing decisions", Result shows that the mean score of male respondents (3.77) higher than female respondents (3.71) but Z value $(0.83)$ is less than 1.96 at 5 percent level of significance. This shows that there is statistically no difference between female and male respondents opinion. Both have same opinion that negative information of celebrity will negatively affect their buying decision".

\section{d. Chi - Square Test}

H0: Gender does not show significant difference in their favorability towards celebrity endorsement.

\begin{tabular}{|l|l|l|l|}
\hline Table No. - 4: Chi - Square Test & Value & df & Asymp. Sig. (2-sided) \\
\hline Pearson Chi-Square & $9.711^{\text {a }}$ & 2 & .008 \\
\hline Likelihood Ratio & 9.795 & 2 & .007 \\
\hline Linear-by-linear Association & 9.468 & 1 & .002 \\
\hline No of Valid Cases & 110 & & \\
\hline
\end{tabular}

Source: Field Survey

The null hypothesis indicates that gender does not show significant difference in their favorability towards celebrity endorsement, to test this hypothesis Chi - Square Test was used, and as per the Table: 4 the 'p' value is $<0.05$. Hence the null hypothesis is rejected and alternate can be accepted.

H0: There exists no significant difference among the gender in their opinion towards the negative impact of the celebrity endorsement.

Table No. - 5: Chi - Square Test

\begin{tabular}{|l|l|l|l|}
\hline & Value & df & Asymp. Sig. (2-sided) \\
\hline Pearson Chi-Square & $.519^{\mathrm{a}}$ & 2 & .771 \\
\hline Likelihood Ratio & .512 & 2 & .774 \\
\hline Linear-by-linear Association & .456 & 1 & .499 \\
\hline No of Valid Cases & 110 & & \\
\hline
\end{tabular}

Source: Field Survey

The null hypothesis indicates that there exists no significant difference among the gender in their opinion towards the negative impact of the celebrity endorsement, to test this hypothesis Chi - Square Test was used, and as per the Table: 5 the 'p' value is $>0.05$. Hence the null hypothesis is accepted.

H0: There exists no significant difference among the gender in their attitude against advertisement

\section{Table No. - 6: Chi - Square Test}

\begin{tabular}{|l|l|l|l|}
\hline & Asymp. Sig. (2-sided) \\
\hline Pearson Chi-Square & Value & df & Asye \\
\hline
\end{tabular}




\begin{tabular}{|l|l|l|l|}
\hline Likelihood Ratio & 5.717 & 2 & .057 \\
\hline Linear-by-linear Association & 5.759 & 1 & .016 \\
\hline No of Valid Cases & 110 & & \\
\hline
\end{tabular}

Source: Field Survey

The null hypothesis indicates that there exists no significant difference among the gender in their attitude against advertisement, to test this hypothesis Chi - Square Test was used, and as per the Table: 6 the 'p' value is $<0.05$. Hence the null hypothesis is rejected and alternate can be accepted.

\section{Major Finding:-}

The following are the major findings of the study which are discussed below:

- Majority of the respondents fall between the age 20 to 30 years.

- Majority of the respondents watch celebrity endorsed ads more repeatedly.

- There is significant impact of celebrities through advertisement on consumers of Shimoga city.

- Female respondents are more strongly convinced to choose the right product and brand if endorsed by celebrity.

- Both male and female respondents have same opinion that trustworthiness of celebrity affects their buying behavior.

- Both male and female respondents have same opinion that expertise of celebrity also influence to their buying behavior.

- Female respondents are more strongly convinced that they purchase their product depending on the image of the celebrity.

- Female respondents are more strongly agree that sex of celebrity also effect to their buying behaviors

- Female respondents are more strongly agree that their buying behavior is influenced by the beauty of celebrity.

- Both male and female respondents have same opinion that negative information of celebrity will negatively affect their buying decision.

\section{Conclusion:-}

In the end we can conclude on the basis of the above research that there is a positive attitude and beliefs of consumers towards celebrity endorsement, especially female consumers are more attracted by celebrities and their promise in advertisement that the product will do something special for them which will transform their life. Similarly, female consumers are very much influenced by celebrity's sex, beauty and image where as with respect trustworthiness and expertise both male and female respondents have same opinion. The negative information of celebrity will negatively affect male and female consumers buying decision due to this reason that the society tends to relate a celebrity's personal life to his profession. Hence the manufacturers and marketers should take care to give all the information which would facilitate the consumers in decision making process. $* * *$

\section{References:-}

1. Rain, Tsz San Kwong (2010), "The effect of celebrity endorsement on young consumers' fashion brand associations in hong kong" The Hong Kong Polytechnic University, 2010

2. Kotler, P (2007), "Marketing Management: Analysis, Planning, Implementation, and Control", 12th edition, Englewood Cliffs, NJ: Prentice-Hall Inc

3. Mehta, A (1994), 'How advertising response modeling (ARM) can increase ad effectiveness', Journal of Advertising Research, 34, No3, p62-74

4. Alsmadi, Sami. (2006), "The Power of Celebrity Endorsement in Brand Choice Behaviour: An EmpiricalStudy of Consumer Attitudes in Jordon," Journal of Accounting-Business \& Management, Vol.13, pp.69-84.

5. Busler, Micheal (2003), "Product Differentiation, Celebrity Endorsements and the Consumer's Perception of Quality", Doctor of Philosophy, Drexer University.

6. Abhishek, Arvind Sahay (2013), "Role of culture in celebrity endorsement: Brand endorsement by celebrities in Indian context” W.P. No. 2013-07-01 